\title{
Genetic transfer of amylovoran and stewartan synthesis between Erwinia amylovora and Erwinia stewartii
}

\author{
Frank Bernhard, ${ }^{1}+$ Dietlinde Schullerus, ${ }^{1}$ Peter Bellemann, ${ }^{1}$ \\ Manfred Nimtz, ${ }^{2}$ David L. Coplin ${ }^{3}$ and Klaus Geider ${ }^{1} \ddagger$ \\ Author for correspondence: Klaus Geider. Tel: +496203106117 or 120. Fax: +496203106122.
}

1 Max-Planck-Institut für medizinische Forschung, Jahnstrasse 29, D-69120 Heidelberg, Germany

2 Gesellschaft für biotechnologische Forschung $\mathrm{mbH}$, Mascheroder Weg 1, D-38124 Braunschweig, Germany

3 Department of Plant Pathology, The Ohio State University, Columbus $\mathrm{OH}$ 43210, USA
DNA fragments with ams genes of Erwinia amylovora and cps genes of Erwinia stewartii were transferred to exopolysaccharide (EPS)-deficient mutants of the other species. The resulting EPSs were characterized by sensitivity to EPSdependent bacteriophages, staining with amylovoran-specific fluoresceinisothiocyanate-labelled lectin and chemical techniques, such as determination of the sugar composition and methylation analysis in order to distinguish between amylovoran and stewartan. Degradation by the stewartan-dependent phage $\phi$-K9 was used to detect stewartan production, and staining with a lectin from Abrus precatorius detected amylovoran capsules. The patterns of sugar linkages were determined by methylation analysis. Stewartan contained a significantly higher glucose to galactose ratio than amylovoran and produced a characteristic signal from 6-linked glucose residues. By these criteria, most $E$. stewartii cps mutants displayed exclusively amylovoran synthesis when complemented with the ams cluster, and $E$. amylovora ams mutants complemented with $E$. stewartii cps genes produced stewartan. The complementation to an EPS-positive phenotype may require most genes of the ams or the cps operon. An exception was an E. stewartii cpsK mutant that made predominantly stewartan when complemented with the ams cosmid. IR spectra showed that both amylovoran and stewartan were acylated when synthesized in E. amylovora, but not in E. stewartii. The amylovoran-producing E. stewartii merodiploids regained virulence to corn seedlings when mucoidy was restored by the ams cluster, but the stewartan-producing $E$. amylovora ams $^{-} /$cps $^{+}$strains were weakly virulent on pear slices and avirulent on apple seedlings.

Keywords: fireblight, Stewart's wilt, complementation, transgenic bacteria, exopolysaccharide synthesis

\section{INTRODUCTION}

Extracellular polysaccharide (EPS) capsules and slime are important to plant-pathogenic bacteria (Leigh \& Coplin, 1992). Capsules protect pathogens against recognition by plant defence mechanisms, bind water to keep the bacteria moist, and retain nutrients and ions released from

† Present address: Freie Universităt Berlin, Institut für Kristallographie, Takustr. 6, D-14195 Berlin, Germany.

$\ddagger$ Present address: Max-Planck-Institut fü Zellbiologie, Rosenhof, D-68526 Ladenburg, Germany.

Abbreviations: EPS, exopolysaccharide; FITC, fluorescein isothiocyanate. damaged plant cells. This not only creates a favourable environment for bacterial multiplication in the intracellular spaces and aids the spread of bacteria through plant tissues, but can also cause vascular occlusions and wilt symptoms (Van Alfen, 1989). Erwinia stewartii (recently reclassified as Pantoea stewartii subsp. stewartii by Mergaert et al., 1993) is the causal agent of Stewart's wilt and blight of corn and is transmitted by the corn flea beetle. Erwinia amylovora is the causal agent of fireblight on pome fruit trees and other rosaceous plants. The capsular EPSs produced by E. amylovora and E. stewartii are called amylovoran and stewartan, respectively, and they are important virulence factors for these pathogens. 
Amylovoran-deficient mutants of E. amylovora are avirulent (Steinberger \& Beer, 1988; Bellemann \& Geider, 1992; Bernhard et al., 1993b) and EPS-deficient mutants of E. stewartii fail to cause wilting and watersoaking, although they can still elicit restricted necrotic lesions (Dolph et al., 1988; Coplin \& Majerczak, 1990).

Amylovoran and stewartan are complex heteropolysaccharides, composed of glucose, galactose and glucuronic acid (Smith et al., 1990; Costa, 1991). They are typical of enteric group I polysaccharides, such as the K30-EPS of Escherichia coli. As for other EPSs in this group, their synthesis is regulated by a complex mechanism involving transcriptional activation of EPS biosynthesis genes by RcsA and RcsB (Bernhard et al., 1990; Gottesman \& Stout, 1991; Poetter \& Coplin, 1991). This suggests that gene clusters for the biosynthesis of group I polysaccharide may have a common evolutionary origin, and by analogy to group II biosynthetic clusters they may share a common organization of genes for production of nucleotide sugar precursors, polymerization of subunits, and transport of the polymer across the inner and outer membranes. Genetic comparison of the ams gene cluster for amylovoran synthesis and the cps gene cluster for stewartan synthesis supports this hypothesis (Bernhard $e t$ al., 1993b). Genes involved in amylovoran synthesis have been cloned in cosmid pEA109 (Bernhard et al., 1993b) and genes encoding stewartan synthesis have been cloned in cosmid pES2144 (Dolph et al., 1988). Transposon mutations in each cosmid were introduced into the chromosome and then used in in trans complementation tests in order to assign mutations to ams and $c p s$ complementation groups. Both plasmids were able to complement EPS mutants of E. stewartii and of $E$. amylovora (Bernhard et al., 1993b). Restoration of EPS synthesis was demonstrated by mucoid appearance, phage typing, and isolation of polysaccharides.

The nature of the EPS produced by the transgenic merodiploids was not determined. The structures of amylovoran and of stewartan (Fig. 1) indicate that genes for certain glycosyltransferases involved in subunit synthesis have diverged between E. amylovora and E. stewartii. Although the sugars and their linkages appear quite similar, three differences exist: (i) the backbone of the repeating unit of stewartan contains a 6-substituted glucose instead of an identically substituted galactose residue in amylovoran; (ii) the branched galactose residue is substituted in position 6 by a glucose residue to about $90 \%$ in stewartan and 10\% in amylovoran; and (iii) the side chain of amylovoran is terminated by a pyruvylated galactose, whereas in stewartan another glucose molecule is attached instead of the pyruvate (M. Nimtz, A. Mort, V. Wray, T. Domke, Y. Zhang, F. Qiu, D. Coplin \& K. Geider, unpublished). Restoration of mucoidy to EPS mutants of the other species raised the question as to the nature of the EPS produced. In this study, we demonstrate that the ability to synthesize either amylovoran or stewartan can be transferred between Erwinia species by cosmid clones containing the large ams or cps gene clusters. Parts of this work have been presented in the proceedings of various meetings (Bernhard et al., 1993a, 1994).

\section{Amylovoran}

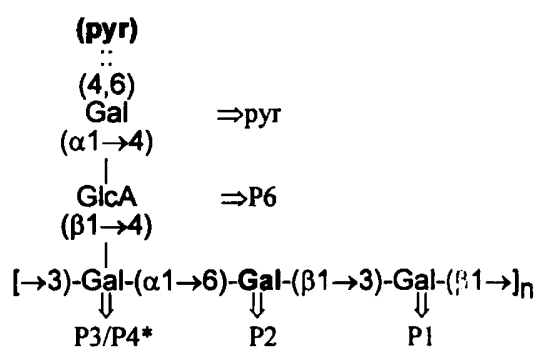

Stewartan

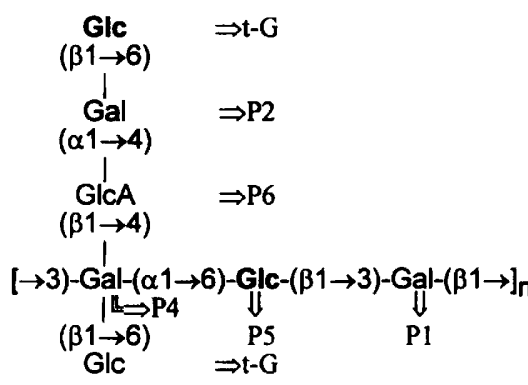

- about $10 \%$ repeating units branched with $(\beta 1 \rightarrow 6) \mathrm{Glc}(\Rightarrow \mathrm{t}-\mathrm{G})$

Fig. 1. Structure of the repeating units of amylovoran and stewartan as derived from NMR spectra of oligosaccharides and from methylation analysis (M. Nimtz and others, unpublished). The assignments $(\Rightarrow)$ refer to the signals listed in Table 3.

\section{METHODS}

Strains and bacteriophages. These are listed in Table 1. Phage PEa1(h) (Hartung et al., 1988) was renamed $\phi$-Ea1h in order to avoid confusion with pEA-plasmids and strain Ea1/79. For propagation, the phages were plated on lawns of strains DC283 (for $\phi-\mathrm{K} 9$ ) or Ea1/79 (for $\phi$-Ea1h) to obtain confluent lysis. The next day, the phages were extracted with $5 \mathrm{ml}$ phage buffer $(0 \cdot 15 \mathrm{M} \mathrm{NaCl}, 2 \mathrm{mM} \mathrm{MgSO}, 10 \mathrm{mM}$ Tris/HCl; $\mathrm{pH} 7.5)$. A titre of $5 \times 10^{9}$ to $5 \times 10^{11}$ p.f.u. $\mathrm{ml}^{-1}$ was usually obtained. For degradation experiments phage $\phi$-K9 was purified by precipitation with $10 \%$ PEG 6000 and $0.5 \mathrm{M} \mathrm{NaCl}$. The precipitate was resuspended in phage buffer or water and the phages stored at $4{ }^{\circ} \mathrm{C}$.

Isolation and sugar analysis of EPS. E. amylovora strains were grown on MM1 agar (Steinberger \& Beer, 1988) with sorbitol and E. stewartii strains on CPG agar (Bradshaw-Rouse et al., 1981). EPS was prepared as described by Bernhard et al. (1993b). The total concentration of EPS was determined by the anthrone method (Spiro, 1966), and galactose was used as a standard. Monosaccharides were analysed according to Chaplin (1982) as methyl glycosides after methanolysis and trimethylsilylation on a Carlo Erba Mega Series gas chromatograph with a $30 \mathrm{~m}$ DB1 capillary column connected to a Kratos MS50 mass spectrometer.

Methylation analysis of EPS and identification of the products. The EPSs were methylated according to Hakomori (1964). The permethylated carbohydrate material was purified 
Table 1. Bacterial strains, plasmids and bacteriophages

\begin{tabular}{|c|c|c|}
\hline $\begin{array}{l}\text { Strain or } \\
\text { plasmid }\end{array}$ & Description & Source or reference \\
\hline \multicolumn{3}{|l|}{ E. amylovora } \\
\hline CFBP1430 & Wild-type & J. Laurent, INRA, Paris \\
\hline $\mathrm{Ea} 1 / 79$ & Wild-type & Falkenstein et al. (1988) \\
\hline Ea1/79-del100 & Deletion of ams $A-F$ and ams $J$, substituted by plasmid pfdB14Z'; $\mathrm{Cm}^{\mathrm{r}}$ & Bugert \& Geider (1995) \\
\hline $\mathrm{Ea} 1 / 79-\mathrm{D} 4$ & $\mathrm{Nal}^{\mathrm{r}}$; amsE4:: Tn 5 & Bernhard et al. (1993b) \\
\hline $\mathrm{Ea} 1 / 79-\mathrm{D} 41$ & $\mathrm{Nal}^{\mathrm{r}} ;$ amsE41::Tn 5 & Bernhard et al. (1993b) \\
\hline \multicolumn{3}{|l|}{ E. stewartii } \\
\hline 449 & Wild-type & W. Zeller (from England 1984) \\
\hline DC283 & SW104 (wild-type), Nal ${ }^{\mathrm{r}}$ & Coplin et al. (1986) \\
\hline GAL8 & DC283 $\Delta(c p s B-$ galE $)$ & Dolph et al. (1988) \\
\hline DM138 & $\mathrm{DC} 283$ cpsB178:: $\mathrm{Tn} 3 \mathrm{HoHo} 1$ & Coplin \& Majerczak (1990) \\
\hline DM144 & DC283 cpsK:: $\operatorname{Tn} 3 \mathrm{HoHo} 1 *$ & Coplin \& Majerczak (1990) \\
\hline DM215 & DC283 cpsD215: : Tn5lac* & D. Coplin \& D. Majerczak, unpublished \\
\hline DM220 & DC283 cpsD449: : $\operatorname{Tn} 5$ lac* & Coplin \& Majerczak (1990) \\
\hline PJD1910 & DC283 cpsC221:: $\operatorname{Tn} 5$ lac & Coplin \& Majerczak (1990) \\
\hline \multicolumn{3}{|l|}{ Plasmids } \\
\hline pEA109 & $\begin{array}{l}15.5 \mathrm{~kb} H i n \mathrm{dIII} \text { fragment with E. amylovora genes ams } H-I-A-B-C- \\
D-E-F-J-K-L \text { in } \mathrm{pVK} 100, \mathrm{Tc}^{\mathrm{r}}\end{array}$ & Bernhard et al. (1993b) \\
\hline pES2144 & $\begin{array}{l}27 \mathrm{~kb} \text { HindIII partial digestion fragment with } E \text {. stewartii genes } \\
c p s A \text { to galE in } \mathrm{pVK} 100, \mathrm{Tc}^{\mathrm{r}}\end{array}$ & Coplin et al. (1986) \\
\hline \multicolumn{3}{|l|}{ Bacteriophages } \\
\hline$\phi-\mathrm{K} 9$ & Host: E. stewartii with capsules & Bradshaw-Rouse et al. (1981) \\
\hline$\phi$-Ea1h & PEa1(h); host: E. amylovora & Hartung et al. (1988) \\
\hline
\end{tabular}

* The designation $c p s D^{\prime}$ used in the text refers to the complementation group $c p s D$ (Dolph et al., 1988), now known to contain four genes, $c p s D, E, F, G$; the old designation $c p s E$ has been renamed $c p s K$.

by chromatography on a Sephadex LH20 column, hydrolysed with $4 \mathrm{M}$ trifluoroacetic acid, reduced by $\mathrm{NaBH}_{4}$ and peracylated as previously described (Nimtz et al., 1990). In order to detect hexuronic acids, the permethylated sample was additionally reduced with $\mathrm{NaBD}_{4}$ and the glucuronic acid converted to glucose with two deuterium atoms incorporated at C6. Analyses were performed using the GC-MS instruments described in the preceding section.

Degradation assays and TLC. EPS $\left(12 \mathrm{mg} \mathrm{ml}^{-1} ; 70 \mu \mathrm{l}\right)$ was mixed with a purified phage $\phi-K 9$ suspension $\left(1 \times 10^{10}\right.$ p.f.u. $\left.\mathrm{ml}^{-1} ; 5 \mu \mathrm{l}\right)$ and incubated overnight at $42^{\circ} \mathrm{C}$. An aliquot of the reaction mixture was then spotted on a silica gel plate $(10 \times 10 \mathrm{~cm}$; 'HPTLC-Fertigplatten Kieselgel 60 ' without fluorescence indicator; Merck) and developed with n-butanol/ $\mathrm{H}_{2} \mathrm{O} /$ ethanol $(5: 4: 5$, by vol.) for $1.5 \mathrm{~h}$ (A. Bermpohl \& $\mathrm{R}$. Eichenlaub, personal communication). The plate was air dried, sprayed with $0.3 \%$ orcinol (Sigma) in $3 \mathrm{M} \mathrm{H}_{2} \mathrm{SO}_{4}$ and incubated for $30-45 \mathrm{~min}$ in a $100^{\circ} \mathrm{C}$ oven.

Acetylation analysis and IR spectroscopy. EPS $(0.5 \mathrm{mg})$ was thoroughly mixed with $\mathrm{KBr}(150 \mathrm{mg})$ and pressed into a translucent disk. Spectra were measured with a Perkin Elmer FT-IR 1760X infrared spectrophotometer. Acetate was determined with a commercial test system (Boehringer Mannheim).

Lectin staining. Bacteria were suspended on a glass slide in $5 \mu \mathrm{l}$ of a commercial solution (Sigma) of FITC-labelled lectin from Abrus precatorius (Jequirity bean). If required, up to $5 \mu$ l of water was added to dilute the bacteria. The cells were visualized with a Zeiss microscope Axiovert $405 \mathrm{M}$ with an oil-immersion lens at $1000 \times$ magnification and filter BP450-490 FT510 LP520.

Virulence assays. The virulence assays of E. amylovora on pear slices were repeated as described previously (Bernhard et al., 1993b) and supplemented by assays with apple seedlings (Malus communis cv. Golden Delicious). Ratings for symptoms on slices of immature pears were: 0 , no symptoms; 1 , little ooze formation and necrosis; 2 , moderate amounts of ooze; 3 , pear slice almost coverd with ooze, necrotic appearance. Six-weekold apple seedlings were inoculated in the centre vein of a leaf with a needle dipped into a bacterial colony. Intermediate stages of symptom formation were not observed in the experiments of this series, which were done in triplicate. Virulence of $E$. stewartii strains on corn seedlings was determined by both a whorl assay for water-soaking (Bernhard et al., 1993b) and a wilting assay. The whorl assay consisted of pipetting $0.1 \mathrm{ml}$ of inoculum into the whorls of 1 -week-old sweet corn seedlings (Zea mays cv. Earliking) without wounding. Inoculum was prepared at $10^{8}$ cells $\mathrm{ml}^{-1}$ in $0.01 \mathrm{M}$ potassium phosphate buffer containing $0.2 \%$ Tween 40 . Symptoms were rated $3 \mathrm{~d}$ after inoculation on a continuous scale: 0 , no symptoms; 1 , scattered water-soaked lesions; 2, numerous water-soaked lesions; 3 , extensive lesions with prolonged water-soaking and oozeforming leaf surfaces. Values reported are means of at least three determinations. To measure wilting ability, seedlings were cut off $2 \mathrm{~cm}$ above the soil line, and $10 \mu \mathrm{l}$ of inoculum was placed on the cut stump. Wilting symptoms were rated on a scale of $0-3$ : 0 , no symptoms; 1 , one or two leaves wilted; 2 , most of plant wilted; 3 , all of plant wilted and necrotic. 


\section{RESULTS}

\section{Properties of E. amylovora and E. stewartii EPS- dependent bacteriophages}

Cloned chromosomal fragments with ams genes of $E$. amylovora in cosmid pEA109 and with cps genes of E. stewartii in cosmid pES2144 (Fig. 2) were able to complement mutations in EPS genes of the other organism to a mucoid phenotype (Bernhard et al., 1993b). In this study, we analysed the type of EPS synthesized after heterologous complementation. For that purpose, two EPS-dependent bacteriophages, $\phi$-Ea1h and $\phi$-K9, were characterized for their ability to distinguish amylovoran and stewartan capsules. Phage $\phi$-Ea1h grew well on $E$. amylovora wild-type strain Ea1/79, but was unable to lyse the EPS-deficient mutant Ea1/79-del100 [ $\Delta a m s A$-amsF] (Table 2). In spot tests on a lawn of E. stewartii wild-type strain DC283, $\phi$-Ea1h produced partial clearing and

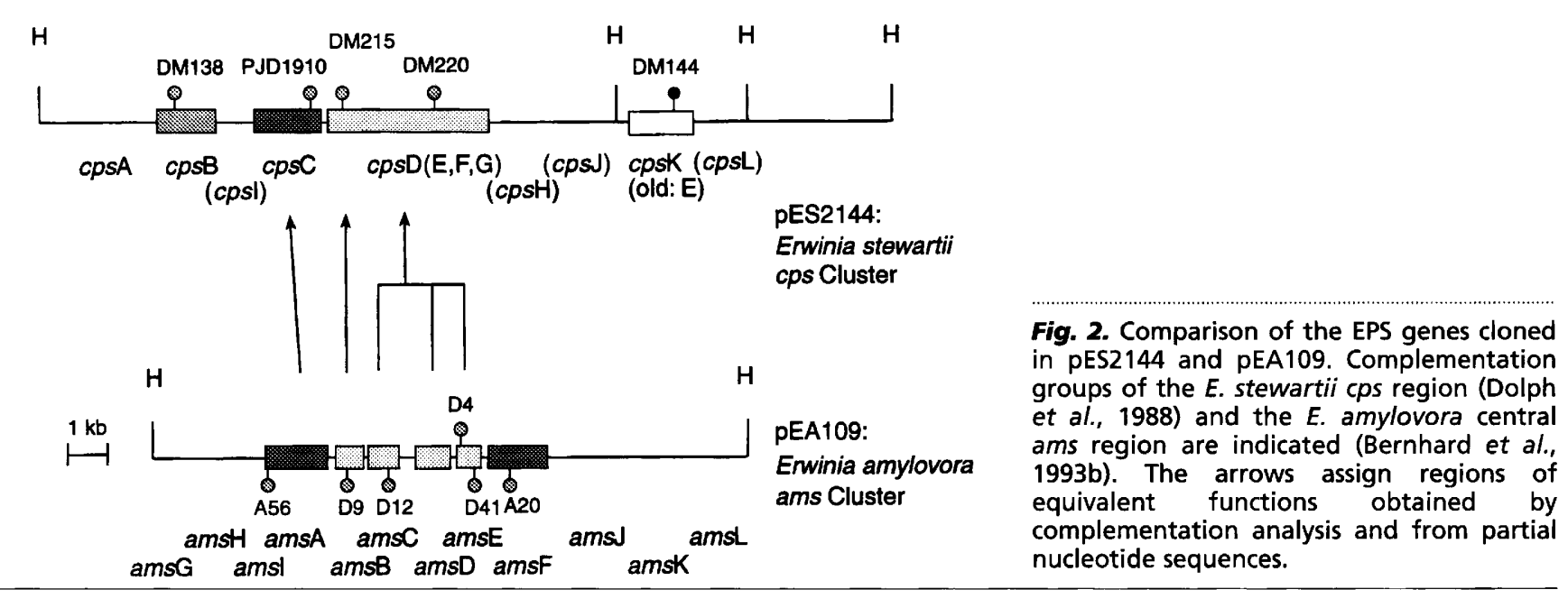

Table 2. Phage sensitivity of Erwinia strains and their virulence on corn seedlings or pear slices and apple seedlings

\begin{tabular}{|c|c|c|c|c|}
\hline \multirow[t]{2}{*}{ Strain } & \multicolumn{2}{|c|}{$\begin{array}{l}\text { Spot test* with } \\
\text { phage }\end{array}$} & \multirow[t]{2}{*}{$\begin{array}{c}\text { Virulence on } \\
\text { corn }(W S / W I) \dagger\end{array}$} & \multirow{2}{*}{$\begin{array}{c}\text { Virulence } \\
\text { on pear } \\
\text { slices/apple } \\
\text { seedlings } \ddagger\end{array}$} \\
\hline & $\phi-\mathbf{K} 9$ & $\phi$-Ea1h & & \\
\hline \multicolumn{5}{|l|}{ E. stewartii } \\
\hline DC.283 & 3 & 1 & $2 \cdot 9 / 2 \cdot 9$ & \\
\hline GAL8 & 0 & 0 & $0 /-$ & \\
\hline DC283(pEA109) & 3 & 1 & $3 \cdot 0 /-$ & \\
\hline $\begin{array}{l}\text { DM138, DM215, } \\
\text { DM220, PJD1910 }\end{array}$ & 0 & 0 & $0-1 \cdot 3 / 0$ & \\
\hline Same with pEA109 & 0 & 1 & $2 \cdot 3-3 \cdot 0 / 2 \cdot 0-2 \cdot 7$ & $0 /-$ \\
\hline DM144 & 0 & 0 & $0 / 0$ & \\
\hline DM144(pEA109) & 2 & 1 & $3 \cdot 0 / 2 \cdot 7$ & $0 /-$ \\
\hline \multicolumn{5}{|l|}{ E. amylovora } \\
\hline Ea $1 / 79$ & 0 & 2 & & $3 / 3$ \\
\hline Ea1/79-del100 & 0 & 0 & & $0 /-$ \\
\hline $\mathrm{Ea} 1 / 79(\mathrm{pES} 2144)$ & 2 & 3 & & $1 \cdot 5 /-$ \\
\hline Ea1/79-D4, -D41 & 0 & 0 & & $0 / 0$ \\
\hline Same with pES2144 & 3 & 3 & & $0-0 \cdot 5 / 0$ \\
\hline
\end{tabular}

* From a phage solution of about $10^{8}$ p.f.u. $\mathrm{ml}^{-1}, 10 \mu \mathrm{l}$ was applied to the agar surface with bacteria of the strains indicated. Rating of spot tests with phages: 0 , no visible reaction; 1 , barely visible halo; 2 , turbid halo; 3, clear lysis.

†WS, whorl assay to determine water soaking ability; WI, cut stump assay to determine virulence from wilting symptoms. - Experiment not done.

$\ddagger$ Symptoms on apple seedlings at two weeks after inoculation ( 0 , no symptoms; 3 , wilting and necrosis). - , Experiment not done. 


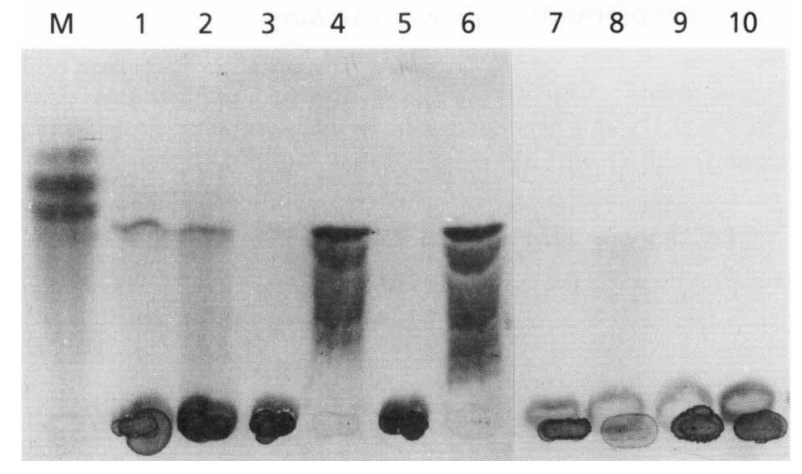

Fig. 3. Separation of phage $\phi-\mathrm{K} 9$ cleavage products on silica gel. Lanes: $M$, marker oligosaccharides (predominantly pentamers and tetramers of glucose; Merck); 1, amylovoran from Ea1/79; 2, amylovoran from Ea1/79 with phage; 3, stewartan from DC283; 4, stewartan from DC283 with phage; 5 , EPS from DM144(pEA109); 6, EPS from DM144(pEA109) with phage; 7, EPS from DM220(pEA109); 8, EPS from DM220(pEA109) with phage; 9, EPS from PJD1910(pEA109); 10, EPS from PJD1910(pEA109) with phage.

scattered plaques in the zone of phage application. The clearing observed on lawns of each species suggests that the $\phi$-Fa1h depolymerase can degrade both amylovoran and stewartan. In another set of experiments we used phage $\phi-\mathrm{K} 9$, isolated from E. stewartii, to characterize EPS degradation. In spot tests, $\phi$-K9 lysed only wild-type capsulated cells of E. stewartii, and not E. amylovora strain Ea1/79. E. stewartii c $p s$ mutants were not permissive for phage $\phi$-K9. Interestingly, plaque formation of $\phi-\mathrm{K} 9$ phages on wild-type E. amylovora carrying plasmid pES2144 indicated that stewartan production was the only factor limiting phage infection.

\section{Characterization of EPS synthesis using Erwinia phages}

When phage $\phi$-Ea1h was applied in a spot assay to a lawn of E. stewartii cps mutants DM138 (mutated in $c p s B$ ), DM144 (cpsK), DM215 (cpsD'), DM220 (cpsD') and PJD1910 ( $c p s C$ ) carrying plasmid pEA109, turbid zones were observed (Table 2). Considering phage dependence on a capsule, the results confirmed complementation of the mutants by pEA109. Complementation of E. amylovora ams mutants with pES2144 also restored lysis by phage $\phi$ Ealh.

To determine the type of EPS produced, we used the stewartan-dependent phage $\phi-K 9$. All E. amylovora ams mutants carrying pES2144 formed cleared zones in spot tests with $\phi-\mathrm{K}$ 9 (Table 2), similar to E. stewartii DC283 and DM144(pEA109). This was in contrast to mutants DM138, DM215, DM220 and PJD1910 with pEA109 (Table 2), which were $\phi$-K9 resistant. We assume that the complemented E. stewartii mutants synthesized amylovoran, which is not degraded by phage $\phi-\mathrm{K} 9$. On the other hand, E. amylovora mutants and wild-type strain Ea1/79 with pES2144 were permissive to phage $\phi$-K9 (Table 2). Results of the spot tests were confirmed by plaque formation (data not shown), which showed not only degradation of stewartan but also propagation of the phages in these bactcria.

\section{Degradation of EPSs by phage $\phi$-K9 depolymerase}

The ability of phage $\phi$-K9 to specifically degrade stewartan was exploited to further analyse the EPS obtained from ams/cps merodiploids. EPS preparations were digested with partially purified phage particles, and the cleavage products were analysed by TLC. The size distribution of degraded stewartan was heterogeneous, but easily distinguishable from intact amylovoran. The main cleavage product of stewartan migrated in the range of heptasaccharides (Fig. 3). In this assay, EPS from DM144(pE 1109) had a pattern almost identical to stewartan (compare lanes 6 and 4 in Fig. 3), whereas EPS from strains DM220(pEA109), PJD1910(pEA109) (Fig. 3 , lanes 8 and 10) and DM215(pEA109) (not shown) was not cleaved by the EPS depolymerase in phage $\phi$-K9 particles. We assume that depolymerase cleaves a bond within the backbone of stewartan, because it reduces the molecular mass of the polymer. Since this enzyme does not affect amylovoran, it is likely that it cleaves adjacent to the glucose in the backbone. These results suggest that the EPSs synthesized after heterologous complementation were similar in structure to either amylovoran or stewartan.

\section{Sugar composition and methylation analysis of EPS from ams/cps merodiploids}

The repeating units of amylovoran and stewartan contain the same sugars, but differ in the amount of glucose (Fig. 1). EPS from the transgenic strains Ea1/79-D4(pES2144) and DM144(pEA109) was similar in sugar composition to EPS from E. stewartii wild-type strain DC283. However, complementation of E. stewartii mutants DM215 (cpsD'), PJD1910 ( $c p s C$ ), and DM220 (cps $D^{\prime}$ ) with pEA109 resulted in a substantial decrease in the ratio of glucose to galactose, resembling the sugar composition of amylovoran (data not shown).

A more precise way to distinguish between amylovoran and stewartan-like EPS was by methylation analysis (Table 3). Since only stewartan contains 6-substituted glucose residues in its repeating unit (Fig. 1), the detection of the respective derivative by methylation analysis offers an easy way of classifying amylovoran and stewartan. Additionally, pyruvylated terminal galactose detected as the respective 4,6-disubstituted derivative was typical of amylovoran. Furthermore, amylovoran contains predominantly 3,4-disubstituted core galactose, whereas in stewartan this residue is almost completely substituted in position 6 by a glucose residue, indicated by the detection of di- or trisubstituted galactose, respectively. For the wild-type EPSs, all of the observed methylated derivatives were consistent with the structures proposed in Fig. 1. The quantity of each derivative depended on the susceptibility of the respective bond to hydrolysis: therefore 
Table 3. Methylation analysis of EPS preparations from wild-type and complemented Erwinia strains

The signals were assigned to sugar residues in Fig. 1 as indicated in the last column: P1 to P6; pyr, pyruval group; t-G, terminal glucose, this compound could be derived in part from sources different from EPS (LPS and branched glucan in the case of E. amylovora strains). The most significant signal for distinction of amylovoran and stewartan is shown in bold print.

\begin{tabular}{|c|c|c|c|c|c|c|c|c|}
\hline $\begin{array}{l}\text { Peracylated } \\
\text { derivative of }\end{array}$ & $\begin{array}{l}\text { Subst. } \\
\text { in posn }\end{array}$ & Ea1/79* & $\begin{array}{c}\text { Ea1/79-D41* } \\
(\mathrm{pES} 2144)\end{array}$ & DC283 & $\begin{array}{c}\text { DM144 } \\
\text { (pEA109) }\end{array}$ & $\begin{array}{c}\text { DM215 } \\
\text { (pEA109) }\end{array}$ & $\begin{array}{c}\text { DM220 } \\
\text { (pEA109) }\end{array}$ & \\
\hline \multicolumn{9}{|l|}{ Galactitol } \\
\hline 2,4,6-Tri-O-methyl- & 3 & ++ & ++ & ++ & ++ & ++ & ++ & /P1 \\
\hline 2,3,4-Tri-O-methyl- & 6 & +++ & + & ++ & ++ & +++ & +++ & $/ \mathrm{P} 2$ \\
\hline 2,6-Di-O-methyl- & $3 ; 4$ & + & + & - & $(+)$ & + & + & /P3 \\
\hline 2,3-Di-O-methyl- & $4 ; 6$ & + & ++ & - & + & + & + & /pyr \\
\hline 2-Mono-O-methyl- & $3 ; 4 ; 6$ & + & $(+)$ & + & + & + & + & $/ \mathrm{P} 4$ \\
\hline \multicolumn{9}{|l|}{ Glucitol } \\
\hline 2,3,4,6-Tetra-O-methyl- & - & + & ++ & +++ & +++ & ++ & ++ & $/ \mathrm{t}-\mathrm{G}$ \\
\hline 2,3,4-Tri- $O$-methyl- & 6 & - & ++ & ++ & ++ & - & - & /P5 \\
\hline 2,3-Di-O-methyl-(6- $\left.\mathrm{D}_{2}\right)-\dagger$ & 4 & + & + & + & + & + & + & /P6 \\
\hline
\end{tabular}

* From E. amylovora cultures, a signal for 3,4,6-tri-O-methylglucitol was detected, which probably originates from contaminating glucan. tObtained by additional $\mathrm{NaBD}_{4}$ reduction of the permethylated sample.

Table 4. FITC-lectin staining of capsules of Erwinia wild-type strains and heterologously complemented mutants

\begin{tabular}{|c|c|c|c|c|}
\hline \multirow[t]{2}{*}{ Host cells } & \multicolumn{4}{|c|}{ Fluorescence $(\%)^{*}$} \\
\hline & Bright & Medium & Weak & None \\
\hline \multicolumn{5}{|l|}{ E. stewartii } \\
\hline DC283 & 0 & 0 & 0 & 100 \\
\hline DC283(pEA109) & 0 & 0 & 100 & 0 \\
\hline DM144(pEA109) & 0 & 0 & 100 & 0 \\
\hline $\begin{array}{l}\text { DM138(pEA109), } \\
\text { DM215(pEA109) }\end{array}$ & 0 & 70 & 0 & 30 \\
\hline $\begin{array}{l}\text { DM220(pEA109), } \\
\text { PJD1910(pEA109) }\end{array}$ & 0 & 100 & 0 & 0 \\
\hline \multicolumn{5}{|l|}{ E. amylovora } \\
\hline $\mathrm{Ea} 1 / 79$ & 10 & 80 & 0 & 10 \\
\hline $\mathrm{Ea} 1 / 79(\mathrm{pES} 2144)$ & 0 & 10 & 0 & 90 \\
\hline $\mathrm{Ea} 1 / 79-\mathrm{D} 41(\mathrm{pES} 2144)$ & 0 & 0 & 1 & 99 \\
\hline \multicolumn{5}{|l|}{$\begin{array}{l}\text { E. amylovora from } \\
\text { pear ooze } \dagger\end{array}$} \\
\hline $\mathrm{Ea} 1 / 79$ & 0 & 20 & 0 & 80 \\
\hline $\mathrm{Ea} 1 / 79(\mathrm{pES} 2144)$ & 0 & 1 & 0 & 99 \\
\hline $\mathrm{Ea} 1 / 79-\mathrm{D} 41(\mathrm{pES} 2144)$ & 0 & 0 & 1 & 99 \\
\hline
\end{tabular}

*'The proportion of cells staining at different intensities is given as the percentage of total cells visualized by transmitted light; about $200-500$ cells were evaluated in one experiment.

†Diluted 1:20 in distilled water. For confirmation the experiments were repeated at least twice.

the data listed in Table 3 are not quantitative. The complemented E. stewartii mutant DM144(pEA109) and the E. amylovora mutant Ea1/79-D41(pES2144) showed the expected amount of 6-substituted glucose, indicating the presence of a stewartan-type backbone in these EPSs. The side chains of the polysaccharides, however, could contain a mixture of stewartan and amylovoran structural motifs. Especially, the glucosylation at position 6 of the side chain galactose apparently competes with the pyruvylation, as is indicated by the detection of varying amounts of the respective galactose derivatives in different mutants. 
E. stewartii mutants DM215 and DM220 complemented with pEA109 produced a polysaccharide very similar to native amylovoran, except that the incidence of glucose at position 6 of the branched galactose residue was slightly higher, as indicated by the ratio of the 3,4- and 3,4,6substituted galactose derivatives.

The detection of 2-and 2,6-substituted glucose in addition to high values of terminal glucose in the EPSs of $E$. amylovora strains Ea1/79 and Ea1/79(pES2144) could be due to contaminating glucan, since a low-molecular-mass EPS type containing only glucose is also found in polysaccharide preparations of $E$. amylovora mutants deficient in amylovoran synthesis (unpublished results; Smith et al., 1995). The presence of branched 1,2-glucan could explain most of the terminal glucose found in EPS isolated from strains Ea1/79 and Ea1/79-D41(pEA109) (Table 3).

\section{Identification of capsular amylovoran by staining with FITC-labelled lectin}

Lectin from Abrus precatorius has a strong affinity for amylovoran (Bellemann et al., 1994), but does not bind to stewartan. We used this property to distinguish between the two EPS types in capsules of cps/ams merodiploids (Table 4). When pEA109 was introduced into E. stewartii wild-type strain DC283, the cells were faintly stained by the lectin, whereas the parent strain was completely unreactive. Conversely, only $10 \%$ of cells from strain Ea1/79(pES2144) were intermediately stained, in contrast to $80 \%$ of the cells from the parent strain without this plasmid (Table 4). These results further demonstrated altered EPS in wild-type strains carrying the heterologous EPS gene cluster. Cells of the complemented ams mutant Ea1/79-D41(pES2144) were only weakly stained with lectin, indicating that this complemented mutant synthesized mostly stewartan. When the $c p s B, c p s C$ and $c_{p s} D^{\prime}$ E. stewartii mutants were complemented with pEA109, they bound the lectin and stained with medium fluorescence. On the other hand, the $c p s K$ mutant DM144 with plasmid pEA109 was weakly stained, similar to DC283(pEA109). This is evidence that DM144(pEA109) produced predominantly stewartan, but that amylovoran was additionally synthesized, at a low level.

\section{IR spectroscopy}

The IR spectra of various EPS preparations from $E$. amylovora and E. stewartii wild-type strains and from ams/cps merodiploids were measured. The IR profile for amylovoran was identical for strain Ea1/79 and for a derivative of strain CFBP1430, isolated in France (not shown). Identity was also found for the spectra of stewartan, when prepared from E. stewartii strains DC283 or 449. Typical differences between amylovoran and stewartan were observed in absorption peaks at 1734 , 1375 and $1254 \mathrm{~cm}^{-1}$ (Fig. 4). The absorption profile at other wavenumbers was similar for amylovoran and stewartan. A band at $1609 \mathrm{~cm}^{-1}$ was slightly shifted to $1647 \mathrm{~cm}^{-1}$ for the EPS preparations and not considered to be significant. When amylovoran was treated with alkali (a)

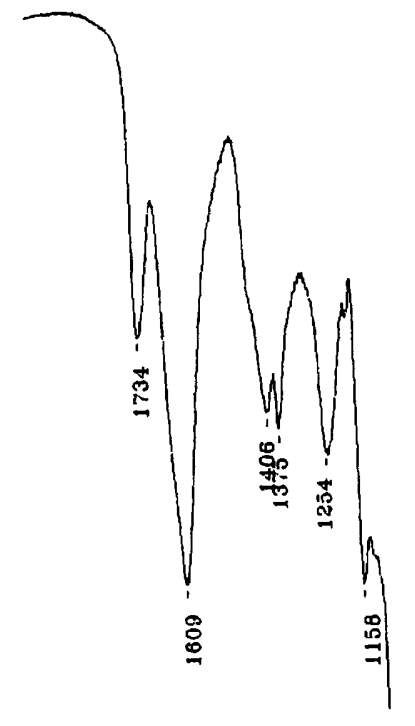

(b)

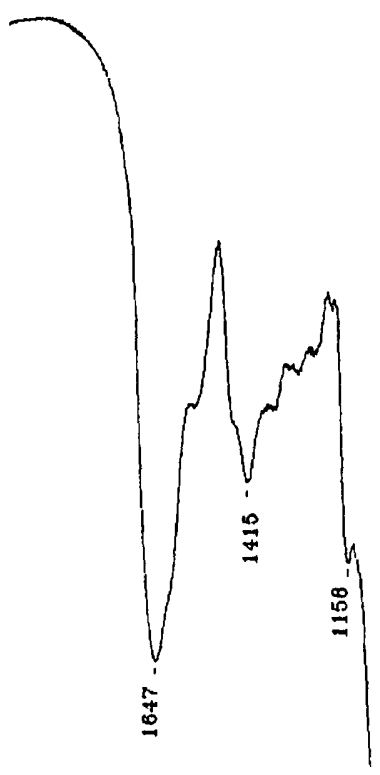

Fig. 4. Comparison of IR spectra of (a) amylovoran from wildtype $E$. amylovora strain Ea1/79 and (b) stewartan from wildtype $E$. stewartii strain DC283. Only the significant range from $1800-1500 \mathrm{~cm}^{-1}$ differing for the two EPS species is shown.

Table 5. Typical signals of IR spectra for various EPS preparations

$1 / v$ refers to the wavenumber in $\mathrm{cm}^{-1}$.

\begin{tabular}{|lccc|}
\hline EPS source & $1 / v=1734$ & $1 / v=1375$ & $\mathbf{1 / v}=\mathbf{1 2 5 4}$ \\
\hline Ea1/79 & + & + & + \\
Ea1/79 (KOH-treated) & - & - & - \\
Ea1/79-D4(pEA109) & + & + & + \\
Ea1/79-D4(pES2144) & + & + & + \\
DC283 & - & - & - \\
DM220(pEA109) & - & - & - \\
PJD1910(pEA109) & - & - & - \\
\hline
\end{tabular}

(20 mM KOH overnight at room temperature) the typical bands at 1734, 1375 and $1254 \mathrm{~cm}^{-1}$ disappeared. No change was seen when stewartan was treated with alkali. The absence of significant amounts of acetyl residues in stewartan was confirmed with a commercial test for acetic acid. When applied to amylovoran, the test was positive, and the acetate content was estimated to be about $7 \%$. No acetate could be detected enzymically after $\mathrm{KOH}$ treatment and dialysis of amylovoran. We concluded that the IR absorption bands differing for the two EPSs were derived from acyl residues, which were removed by alkaline hydrolysis of amylovoran. Although stewartan is not normally acylated, the absorption pattern changed when it was synthesized in E. amylovora strain Ea1/79D4(pES2144) (Table 5). The presence of the three peaks suggested acylation of stewartan by the E. amylovora 
merodiploid. On the other hand, no acyl groups were found in IR spectra of EPS from strains DM220(pEA109) and PJD1910(pEA109) (Table 5). It appears that E. stewartii strains derived from DC283 were unable to decorate any EPS with acyl residues. Stewartan from E. stewartii strain 449 was also not acylated.

\section{Virulence of ams/cps merodiploids}

In previous studies, mutants with transposon insertions in cps genes of E. stewartii showed a greatly reduced ability to damage corn seedlings. The water-soaking ability of different $c p s$ mutants varied and was probably affected by relative humidity (Coplin \& Majerczak, 1990). Virulence with the whorl assay (Bernhard et al., 1993b) was confirmed for transgenic E. stewartii cps mutants with pEA109 by application of bacteria into the pseudostem (whorl) of the seedlings. E. stewartii cps mutants complemented with pEA109 regained the ability to cause watersoaked lesions and to cause wilt (Table 2). The virulence of wild-type strain DC283 was unaffected by pEA109 carriage. None of the E. stewartii strains carrying pEA109 was pathogenic on immature pears.

In contrast to the heterologously complemented cps mutants on corn seedlings, the E. amylovora ams mutants carrying pES2144, were barely virulent on pear slices (Table 2). Even wild-type strain Ea1/79 carrying pES2144 showed reduced virulence. When ooze from inoculated pear slices was diluted and capsulated bacteria were stained with FITC-labelled lectin, the proportion of positively staining capsules of Ea1/79(pES2144) and Ea1/79-D41(pES2144) was found to be much lower in planta than in culture, as already found for the wild-type E. amylovora strain Ea1/79 (Table 4). E. amylovora strain Ea1/79-D4(pES2144) did not produce any symptoms when assayed on apple seedlings (Table 2).

\section{DISCUSSION}

The heteropolysaccharides amylovoran and stewartan are related in sugar composition (Fig. 1) but different in structure. In the case of amylovoran, the backbone of the repeating unit contains only galactose residues. A galactose and a glucuronic acid residue form the side chain. Stewartan contains glucuronic acid, galactose and glucose in a ratio of $1: 3: 3$, and glucose residues could be located in the backbone and in the side chain (Costa, 1991; M. Nimtz and others, unpublished). An oligosaccharide of about seven residues was observed after cleavage of stewartan by $\phi$-K9 depolymerase. Differences in EPS structure may be important for the interactions of these two plant pathogens with their hosts.

In previous studies, E. stewartii cps mutants with the cloned ams gene cluster and E. amylovora ams mutants with the cloned $c p s$ gene cluster regained mucoidy (Bernhard $e t$ al., 1993b), suggesting functional equivalence of some of the EPS genes. The ams and $c p s$ clusters have recently been compared by sequence analysis. The ams operon contains 12 genes (Bugert \& Geider, 1995), and sequence data from E. stewartii (D. Coplin \& D. Majerjak, unpublished) suggest that the cps cluster has a similar organization, including many genes homologous to ams genes.

Our finding that FITC-labelled lectin from $A$. precatorius specifically binds to amylovoran, but not to stewartan, allowed the distinction of the two EPS capsules by fluorescence microscopy. Differences in capsule staining within a population of merodiploids might reflect individual levels of amylovoran synthesis. However, the brightness of stained capsules and their frequency in a cell population is not a completely reliable way to determine amylovoran synthesis in individual bacteria, due to loose association of capsules with the E. amylovora cells (Politis \& Goodman, 1980). To further distinguish between amylovoran and stewartan production by the interspecific transconjugants, we used spot tests with EPS-specific phages, and sugar composition and methylation analysis of the EPSs from the complemented mutants. Phage $\phi$ Ea1h from E. amylovora (Hartung et al., 1988) reacted only with capsulated cells of E. amylovora and E. stewartii. Bacteriophage $\phi$-K9 from E. stewartii (Bradshaw-Rouse et al., 1981) was strictly dependent on the presence of stewartan, presumably by its recognition of the glucose residue in the backbone. The results of phage sensitivity tests were confirmed by using the depolymerase activity present in purified preparations of $\phi$-K9 virions to break down stewartan, which was analysed by TLC on silica gel. Degradation of EPS from DM144(pEA109) and Ea1/79D41(pES2144) by $\phi$-K9 depolymerase indicated that the EPS synthesized was stewartan. A unique signal for $1 \rightarrow$ 6-linked glucose was obtained by methylation analysis for the repeating unit of stewartan. The sugar with this property was absent in amylovoran, and the signal could be used to exclude low quantities of stewartan in EPS from the heterologously complemented cps mutants DM215(pEA109) and DM220(pEA109).

By these criteria, E. amylovora strains with mutations in ams $A$ through ams $F$ carrying pES2144 synthesized EPS with properties of stewartan and, conversely, the $E$. stewartii strains with mutations in $c p s B$ through $c p s D^{\prime}$ carrying pEA109 produced EPS with properties of amylovoran. Therefore, EPS production in these strains was due to substitution of a major part of the biosynthetic pathway, rather than complementation of single genes. An exception was the E. stewartii c $p s K$ mutant, which behaved like the wild-type strain when complemented with pEA109 and synthesized a small amount of amylovoran in addition to near-normal amounts of stewartan. In this case, it appears that $c p s K$ has a similar function in both Erwinia species. This could be a step either in synthesis of nucleotide-sugar precursors or in assembly and transport of the repeating unit.

The ability of the ams and the $c p s$ genes carried in pEA109 and pES2144 to direct synthesis of foreign EPS in another species allows us to form several hypotheses about the functions of the genes in these clusters. The ams region on pEA109 and the cps genes on pES2144 encode the genetic information for most of the glycosyltransferases needed to form entire repeating units. The cloned fragments may 
not contain all the genes needed for EPS synthesis, since there are mutations of E. amylovora (Bellemann \& Geider, 1992) and E. stewartii (D. Coplin \& D. Majerczak, unpublished) that are apparently unlinked to the ams and cps clusters. Since synthesis of amylovoran or stewartan has not been observed in Escherichia coli K12 strains harbouring plasmids pEA109 or pES2144, it is possible that these unlinked genes encode factors specific to EPS synthesis in Erwinia, rather than common factors such as rcs regulatory proteins. Common steps in EPS biosynthesis between the two Erwinia species may also include a similar undecaprenol lipid carrier and synthesis of the same UDP-sugar precursors. It is unlikely that the cloned ams and cps regions contain genes for undecaprenol synthesis, since deletion of these regions does not affect LPS synthesis. The EPSs from E. amylovora and $E$. stewartii differ in acylation. The acyltransferases of $E$. amylovora can apparently modify stewartan, since the EPS from D4(pES2144) was acylated, but the transacylase genes may not be a part of the ams cluster, because EPS from E. stewartii strains carrying pEA109 was not acylated. The clusters do, however, contain a similar region for synthesis of nucleotide sugars, which includes galE (Metzger et al., 1994) and an ORF with homology to galU (L. Kolb \& K. Geider, unpublished) that is located to the right of the cps region in E. stewartii (Dolph et al., 1988; D. Coplin \& D. Majerczak, unpublished), and to the right of the ams operon in E. amylovora (P. Bugert, S. Bereswill \& K. Geider, unpublished).

For O-antigens, the serotype can depend on the acetylation pattern (Yao \& Valvano, 1994). Despite its acylation, stewartan synthesized in E. amylovora strains did not substitute for amylovoran in pathogenesis, since pES2144 barely restored virulence of ams mutants assayed on pear slices and had no effect on virulence of these strains when assayed on apple seedlings. The inability of stewartan to restore virulence to ams mutants could be due to a failure to block host defence reactions by harpin. This protein is an important factor for induction of the hypersenstive reaction by E. amylovora (Wei et al., 1992). On the other hand, the vascular pathogen E. stewartii appears to be less dependent on the type of EPS produced, since the virulence of $c p s$ mutants to corn can be restored by pEA109. This may reflect the lack of an induced resistance response in corn to non-capsulated E. stewartii, so that there is no need for a particular capsule to protect the bacterium against host defences. It is also interesting that the production of amylovoran by E. stewartii did not extend its host range to pears. On the other hand, the results of this study show that there are no inherent barriers to the expression of heterologous EPS genes within the Erwinias. In comparable experiments, the expression of Klebsiella K2 capsular polysaccharide in Escherichia coli and in various Klebsiella serotypes was obtained after transfer of the cloned cps gene cluster (Arakawa et al., 1991). For Escherichia coli, a single glycosyltransferase gene could complement in pathways for LPS synthesis, resulting in hybrid $\mathrm{O}$-antigens (Kogan et al., 1993). For E. amylovora and E. stewartii, more information about the functions and expression of the ams and the $c p s$ genes is required to achieve gene-to-gene complementation.

\section{REFERENCES}

Arakawa, Y., Ohta, M., Wacharotayankun, R., Mori, M., Kido, N., Ito, H. \& Komatsu, T. (1991). Biosynthesis of Klebsiella K2 capsular polysaccharide in Escherichia coli HB101 requires the functions of $r m p \mathrm{~A}$ and the chromosomal cps gene cluster of the virulent strain Klebsiella pneumoniae Chedid (O1:K2). Infect Immun 59, 2043-2050.

Bellemann, P. \& Geider, K. (1992). Localization of transposon insertions in pathogenicity mutants of Erwinia amylovora and their biochemical characterization. J Gen Microbiol 138, 931-940.

Bellemann, P. Bereswill, S., Berger, S. \& Geider, K. (1994). Visualization of capsule formation by Erwinia amylovora and assays to determine amylovoran synthesis. Int J Biol Macromol 16, 290-296.

Bernhard, F., Poetter, K., Geider, K. \& Coplin, D. (1990). The $r c s$ A gene of Erwinia amylovora: identification, nucleotide sequence, and regulation of exopolysaccharide biosynthesis. Mol Plant-Microbe Interact 3, 429-437.

Bernhard, F., Bellemann, P., Bugert, P., Coplin, D. L. \& Geider, K. (1993a). Heterologous expression of EPS-genes in Erwinia amylovora and Erwinia stewartii. Acta Hortic 338, 265-272.

Bernhard, F., Coplin, D. L. \& Geider, K. (1993b). A gene cluster involved in amylovoran synthesis of Erwinia amylovora: characterization and its relationship to cps genes in Erwinia stewartii. Mol Gen Genet 239, 158-168.

Bernhard, F., Coplin, D. L. \& Geider, K. (1994). Genetic characterization of a DNA region involved in amylovoran synthesis of Erwinia amylovora by complementation of Erwinia stewartii cps mutants. In Plant Pathogenic Bacteria, 8th International Conference, Versailles (France), 1992, pp. 539-544. Edited by M. Lemattre, S. Freigoun, K. Rudolph \& J. G. Swings. Paris: INRA, ORSTOM.

Bradshaw-Rouse, J. J., Whatley, M. A., Coplin, D. L., Woods, A., Sequeira, L. \& Kelman, A. (1981). Agglutination of strains of Erwinia stewartii with a corn agglutinin: correlation with extracellular polysaccharide production and pathogenicity. Appl Environ Microbiol 42, 344-350.

Bugert, P. \& Geider, K. (1995). Molecular analysis of the ams operon required for exopolysaccharide synthesis of Erwinia amylovora. Mol Microbiol 15, 917-933.

Chaplin, M. F. (1982). A rapid and sensitive method for the analysis of carbohydrate components in glycoproteins using gas-liquid chromatography. Anal Biochem 123, 336-341.

Coplin, D. L. \& Majerczak, D. R. (1990). Extracellular polysaccharide genes in Erwinia stewartii: directed mutagenesis and complementation analysis. Mol Plant-Microbe Interact 3, 286-292.

Coplin, D. L., Frederick, R. D., Majerczak, D. R. \& Haas, E. S. (1986). Molecular cloning of virulence genes from Erwinia stewartii. J Bacteriol 168, 619-623.

Costa, J. B. (1991). Structural studies of some viscous, acidic bacterial exopolysaccharides. PhD thesis, Ohio State University.

Dolph, P. J., Majerczak, D. R. \& Coplin, D. L. (1988). Characterization of a gene cluster for exopolysaccharide biosynthesis and virulence in Erwinia stewartii. J Bacteriol 170, 865-871.

Falkenstein, H., Bellemann, P., Walter, S., Zeller, W. \& Geider, K. (1988). Identification of Erwinia amylovora, the fireblight pathogen, by colony hybridization with DNA from plasmid pEA29. Appl Environ Microbiol 54, 2798-2802.

Gottesman, S. \& Stout, V. (1991). Regulation of capsular polysaccharide synthesis in Escberichia coli. Mol Microbiol 5, 1599-1606.

Hakomori, S. (1964). A rapid permethylation of glycolipid, and 
polysaccharide catalyzed by methylsulfinyl carbanion in dimethyl sulfoxide. $J$ Biochem 55, 205-207.

Hartung, J. S., Fulbright, D. W. \& Klos, E. J. (1988). Cloning of a bacteriophage polysaccharide depolymerase gene and its expression in Erwinia amylovora. Mol Plant-Microbe Interact 1, 87-93.

Kogan, G., Haraguchi, G., Hull, S. I., Hull, R. A., Shashkov, A. S., Jann, B. \& Jann, K. (1993). Structural analysis of O4-reactive polysaccharides from recombinant Escherichia coli. Changes in the O-specific polysaccharides induced by cloning of the $r f b$ genes. Eur J Biochem 214, 259-265.

Leigh, J. A. \& Coplin, D. L. (1992). Exopolysaccharides in plantbacterial interactions. Annu Rev Microbiol 46, 307-346.

Mergaert, J., Verdonck, L. \& Kersters, K. (1993). Transfer of Erwinia ananas (synonym, Erwinia uredovora) and Erwinia stewartii to the genus Pantoea emend. as Pantoea ananas (Serrano 1928) comb. nov. and Pantoea stewartii (Smith 1898) comb. nov., respectively, and description of Pantoea stewartii subsp. indologenes subsp. nov. Int J Syst Bacteriol 43, 162-173.

Metzger, M., Bellemann, P., Bugert, P. \& Geider, K. (1994). Genetics of galactose metabolism of Erwinia amylovora and its influence on polysaccharide-synthesis and virulence of the fire blight pathogen. J Bacteriology 176, 450-459.

Nimtz, M., Noll, G. \& Pâques, E.-P. (1990). Carbohydrate structures of a human tissue plasminogen activator variant expressed in recombinant Chinese hamster ovary cells. FEBS Lett 271, 14-18.

Poetter, K. \& Coplin, D. L. (1991). Structural and functional analysis of the rcsA gene from Erwinia stewartii. Mol Gen Genet 229, 155-160.
Politis, D. J. \& Goodman, R. N. (1980). Fine structure of extracellular polysaccharide of Erwinia amylovora. Appl Environ Microbiol 40, 596-607.

Smith, A. R. W., Rastall, R. A., Rees, N. H. \& Hignett, R. C. (1990). Structure of the extracellular polysaccharide of Erwinia amylovora: a preliminary report. Acta Hortic 273, 211-219.

Smith, A. R. W., Rastall, R. A., Blake, P. \& Hignett R. C. (1995). Gluco-oligosaccharide production by a strain of Erwinia amylovora. Microbios 83, 27-39.

Spiro, R. G. (1966). Analysis of sugars found in glycoproteins. Methods Enzymol 8, 3-26.

Steinberger, E. M. \& Beer, S. V. (1988). Creation and complementation of pathogenicity mutants of Erwinia amylovora. Mol Plant-Microbe Interact 1, 135-144.

Van Alfen, N. K. (1989). Reassessment of plant wilt toxins. Annu Rev Pbytopatbol 27, 551-550.

Wei, Z. M., Laby, R. J., Zumoff, C. H., Bauer, D. W., He, S. Y., Collmer, A. \& Beer, S. V. (1992). Harpin, elicitor of the hypersensitive response produced by the plant pathogen Erwinia amylovora. Science 257, 85-88.

Yao, Z. \& Valvano, M. A. (1994). Genetic analysis of the O-specific lipopolysaccharide biosynthesis region $(r f b)$ of Escherichia coli K-12 W3310: identification of genes that confer group 6 specificity to Shigella flexneri serotypes Y and 4a. J Bacteriol 176, 4133-4143.

Received 2 October 1995; revised 15 December 1995; accepted 4 January 1996. 